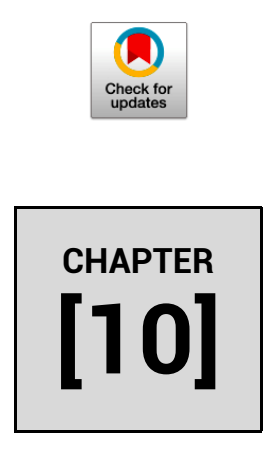

\title{
Remediation of heavy metals using non-conventional adsorbents and biosurfactant-producing bacteria
}

\author{
Swati Rastogi* and Rajesh Kumar
}

Rhizosphere Biology Laboratory, Department of Microbiology, Babasaheb Bhimrao Ambedkar University (A Central University), Vidya Vihar Raebareli Road, Lucknow, India

ABSTRACT

Heavy metal pollution in the ecosystem has attracted worldwide attention due to the persistent non-biodegradable toxic nature that affects not only human beings but also animals and vegetation. Instead of using available conventional techniques, the focus has been shifted to utilize eco-friendly, cost-effective, integrated remediation approaches that are simple, non-conventional with design flexibility and does not harm the prevailing surroundings. The main approaches utilized for remediation of heavy metal contaminated soils are sand capping or land filling, phytoremediation, bioremediation, washing, electro-chemical remediation, stabilization, soil replacement, phytoextraction, phytovoltalization, etc., but again they have their own merits and demerits. Many treatment technologies are employed at industrial scale for HM removal from wastewater effluents such as chemical precipitation, flocculation, coagulation, solvent extraction, adsorption, complexation, electro-kinetics, membrane filtration, etc. Therefore, the present chapter critically highlights the role of non-conventional adsorbents and bacterial surfactants as the best alternative technique for heavy metal remediation from contaminated soil and water systems.

\section{KEYWORDS}

Adsorbents, Bio-surfactants, Environmental sustainability, Heavy metals

$\triangle 6$ Swati Rastogi, Email: sswatirrastogi73@gmail.com

(C) 2020 | Agro Environ Media | Agriculture and Environmental Science Academy, Haridwar, India 


\section{Introduction}

The industrial processes/discharge and natural weathering are the two main causes of heavy metal (HM) pollution due to which the latter are dispersed into land and water ecosystem leading to environmental pollution. The gradual acclimatisation of these soluble metal ions above their permissible limits and their accumulation in the food web exerts adverse toxic and malignant effects on the living forms (Kumar et al., 2019). These HM ions are persistent and can cause their effect even at very low concentrations. HM toxicity directly affects the normal functioning of the body. Lead $(\mathrm{Pb})$ and Cadmium $(\mathrm{Cd})$ are considered as one of the two deadliest HM ions whose persistence over a long period of time can affect central nervous system, can cause damage to vital organs such as lung and kidneys. The main sources of $\mathrm{Pb}$ and $\mathrm{Cd}$ are paint and pigment industries, electroplating and battery industries. $\mathrm{Cd}$ is also released into the environment as a byproduct during smelting of $\mathrm{Pb}$ and Zinc (Zn) (Dinis and Fiuza, 2011). Mercury (Hg) being another toxic HM ion is discharged through minings, volcanic eruptions, pharmaceutical industries, etc. whose high concentration can affect immune system leading to abnormal brain functioning (Rastogi et al., 2019; Mahmud et al., 2016). Table 1 discusses about some of the common heavy metal ions, source of discharge, permissible limits in different ecosystem and their harmful effects.

Many treatment technologies are employed at industrial scale for HM removal from wastewater effluents such as chemical precipitation, flocculation, coagulation, solvent extraction, adsorption, complexation, electro-kinetics, membrane filtration, etc. (Mohammed et al., 2015) but these are conventional approaches and have their own limitations which are discussed in the coming section (Table 2). The main approaches utilized for remediation of heavy metal contaminated soils are sand capping or land filling, phytoremediation, bioremediation, washing, electrochemical remediation, stabilization, soil replacement, phytoextraction, phytovoltalization, etc. (Koptsik, 2014; Kumar et al., 2019) but again they have their own merits and demerits. The focus has been shifted towards assessing non-conventional approaches or materials to remediate such noxious HM ions from the environment.

\section{Conventional approaches and their limitations}

The era of wastewater treatment has given birth to many physico-chemical conventional approaches that has been raised to an alarming rate leading to the generation of secondary toxic sludge/by-products, requires large operational cost and expensive chemicals plus can work efficiently at high concentrations only due to which more attention is diverted towards nonconventional approaches or employing conventional approach using non-conventional methods 
Table 1. Sources of heavy metals, types, their permissible limits, and harmful effect on living and non-living system.

\begin{tabular}{|c|c|c|c|c|c|}
\hline $\begin{array}{l}\text { Heavy } \\
\text { metal }\end{array}$ & Sources & $\begin{array}{l}\text { Permissible } \\
\text { limit in soils } \\
(\mathrm{mg} / \mathrm{kg}) \\
\text { adapted from } \\
\text { Deuel and } \\
\text { Holliday (1994) }\end{array}$ & $\begin{array}{l}\text { Permissible } \\
\text { limit in } \\
\text { drinking water } \\
(\mathrm{mg} / \mathrm{L}) ; \text { WHO } \\
\text { standards }\end{array}$ & Toxic effect & References \\
\hline $\mathrm{Cd}$ & $\begin{array}{l}\text { Electroplating, } \\
\text { Pigmented } \\
\text { products, mining } \\
\text { etc. }\end{array}$ & $0.01-0.7$ & 0.005 & $\begin{array}{l}\text { Damage to } \\
\text { liver, } \\
\text { kidneys, } \\
\text { hypertension, } \\
\text { carcinogenic }\end{array}$ & $\begin{array}{l}\text { Pavon et al. (2019); } \\
\text { Das and Al-Naemi } \\
\text { (2019) }\end{array}$ \\
\hline $\mathrm{Cu}$ & $\begin{array}{l}\text { Wood processing } \\
\text { industries }\end{array}$ & $2-100$ & 1.0 & $\begin{array}{l}\text { Dermatitis, } \\
\text { chronic } \\
\text { asthma, } \\
\text { generation of } \\
\text { free radicals }\end{array}$ & Alak et al. (2019) \\
\hline As & $\begin{array}{l}\text { Wood processing } \\
\text { industries, } \\
\text { through } \\
\text { herbicides, mining, } \\
\text { etc. }\end{array}$ & $1-50$ & 0.05 & $\begin{array}{l}\text { Visceral } \\
\text { cancers, } \\
\text { kidney and } \\
\text { vascular } \\
\text { disease, }\end{array}$ & $\begin{array}{l}\text { Navasumrit et al. } \\
\text { (2019) }\end{array}$ \\
\hline $\mathrm{Pb}$ & $\begin{array}{l}\text { Paint and pigment } \\
\text { industries, } \\
\text { batteries, } \\
\text { automobiles, etc. }\end{array}$ & $2-200$ & 0.05 & $\begin{array}{l}\text { Damage to } \\
\text { brain, fetus, } \\
\text { liver, } \\
\text { kidneys, } \\
\text { bones, }\end{array}$ & Chung et al. (2019) \\
\hline $\mathrm{Zn}$ & $\begin{array}{l}\text { Electrolysis, } \\
\text { Galvanization } \\
\text { processes, paints, } \\
\text { fertilizers, etc. }\end{array}$ & $10-300$ & 5.0 & $\begin{array}{l}\text { Nervous } \\
\text { sytem } \\
\text { dysfunction, } \\
\text { growth } \\
\text { retardation }\end{array}$ & Poole et al. (2019) \\
\hline $\mathrm{Hg}$ & $\begin{array}{l}\text { Soil leaching, fossil } \\
\text { fuel burning, etc. }\end{array}$ & $0.01-0.3$ & 0.001 & $\begin{array}{l}\text { Circulatory } \\
\text { and nervous } \\
\text { system } \\
\text { disorders, }\end{array}$ & Cariccio et al. (2019) \\
\hline $\mathrm{Fe}$ & $\begin{array}{l}\text { Smelting, } \\
\text { fertilizers, mining, } \\
\text { etc. }\end{array}$ & $7000-550,000$ & 0.1 & $\begin{array}{l}\text { Retarted } \\
\text { growth, low } \\
\text { RBC count }\end{array}$ & Hino et al. (2019) \\
\hline
\end{tabular}


Table 2. Merits and demerits of common conventional approaches of wastewater treatment.

\begin{tabular}{|c|c|c|c|c|}
\hline Technology & Heavy metal & Advantages & Disadvantages & References \\
\hline $\begin{array}{l}\text { Chemical } \\
\text { precipitation }\end{array}$ & $\begin{array}{l}\mathrm{Cu}(\mathrm{II}), \mathrm{Zn}(\mathrm{II}), \mathrm{Cd} \\
(\mathrm{II}), \mathrm{Pb}(\mathrm{II})\end{array}$ & $\begin{array}{l}\text { Cheap and } \\
\text { Simple method }\end{array}$ & $\begin{array}{l}\text { Sludge generation, } \\
\text { costly, can't detect low } \\
\text { metal ion concentration }\end{array}$ & $\begin{array}{l}\text { Huang et al. } \\
\text { (2019); Wu (2019) }\end{array}$ \\
\hline Ion exchange & $\begin{array}{l}\mathrm{Pb}(\mathrm{II}), \mathrm{Cu}(\mathrm{II}), \mathrm{Ni} \\
\text { (II) }\end{array}$ & $\begin{array}{l}\text { Regeneration of } \\
\text { resins is possible }\end{array}$ & $\begin{array}{l}\text { Expensive, secondary } \\
\text { pollutant generation }\end{array}$ & $\begin{array}{l}\text { Nemati et al. } \\
\text { (2019); Ma et al. } \\
\text { (2019) }\end{array}$ \\
\hline $\begin{array}{l}\text { Coagulation/ } \\
\text { Flocculation }\end{array}$ & $\begin{array}{l}\mathrm{Pb}(\mathrm{II}), \mathrm{Cd}(\mathrm{II}), \mathrm{Cu} \\
\text { (II), } \mathrm{Cr}(\mathrm{III}), \mathrm{Ni} \\
\text { (II), } \mathrm{Co}(\mathrm{II}), \mathrm{As} \\
\text { (III) }\end{array}$ & $\begin{array}{l}\text { Sludge settling } \\
\text { characteristics }\end{array}$ & $\begin{array}{l}\text { High chemicals input } \\
\text { and maintenance }\end{array}$ & $\begin{array}{l}\text { Bora and Dutta } \\
\text { (2019) }\end{array}$ \\
\hline $\begin{array}{l}\text { Membrane } \\
\text { filtration }\end{array}$ & $\begin{array}{l}\mathrm{Zn}(\mathrm{II}), \mathrm{Cd}(\mathrm{II}), \mathrm{Pb} \\
\text { (II) }, \mathrm{Hg}(\mathrm{II})\end{array}$ & Highly efficient & $\begin{array}{l}\text { A complex and costly } \\
\text { method }\end{array}$ & $\begin{array}{l}\text { Ye et al. (2019); } \\
\text { Efome et al. } \\
\text { (2019) }\end{array}$ \\
\hline Floatation & $\begin{array}{l}\mathrm{Sr}(\mathrm{II}), \mathrm{La}(\mathrm{III}), \mathrm{As} \\
(\mathrm{V})\end{array}$ & $\begin{array}{l}\text { Selectivity, } \\
\text { efficiency }\end{array}$ & $\begin{array}{l}\text { High maintenance and } \\
\text { operational conditions }\end{array}$ & $\begin{array}{l}\text { Elazzouzi et al. } \\
\text { (2019); Taseidifar } \\
\text { et al. (2019) }\end{array}$ \\
\hline $\begin{array}{l}\text { Electro-chemical } \\
\text { treatment }\end{array}$ & $\begin{array}{l}\mathrm{Cd}(\mathrm{II}), \mathrm{Pb}(\mathrm{II}), \mathrm{Zn} \\
\text { (II) }\end{array}$ & $\begin{array}{l}\text { Fast and } \\
\text { controlled } \\
\text { process }\end{array}$ & High operational cost & $\begin{array}{l}\text { Giwa et al. (2019); } \\
\text { Delil et al. (2020) }\end{array}$ \\
\hline Adsorption & $\begin{array}{l}\mathrm{Cr}(\mathrm{VI}), \mathrm{Zn}(\mathrm{II}), \mathrm{Pb} \\
\text { (II), } \mathrm{Cd}(\mathrm{II}), \mathrm{Cu}(\mathrm{II})\end{array}$ & $\begin{array}{l}\text { Cost effective by } \\
\text { using low cost } \\
\text { adsorbents, } \\
\text { Biosorption-a } \\
\text { new vista in } \\
\text { adsorption } \\
\text { technology }\end{array}$ & $\begin{array}{l}\text { Process efficiency } \\
\text { depends on type of } \\
\text { adsorbent used }\end{array}$ & $\begin{array}{l}\text { Kyzas et al. } \\
\text { (2019); Sharma et } \\
\text { al. (2019) }\end{array}$ \\
\hline
\end{tabular}

or materials (Rangabhashiyam et al., 2019). However, the advantage and disadvantages of some of the common conventional approaches have been summarized in Table 2.

\section{Sustainable amendments for heavy metal remediation}

\section{Adsorption}

Among all the conventional approaches available for remediation of heavy metals, adsorption is the most appropriate ancient technology as it is simple to perform, requires less operational cost and has design flexibility. C.W. Scheele in 1773 showed first time the uptake of gases onto charcoal and clays (Bhatnagar and Minocha, 2006) but the term 'Adsorption' was coined by a German physicist Heinrich Kayser in 1881 (Calvert, 1990). It is defined as a surface phenomenon which involves adherence or binding of a chemical species (known as adsorbate) on to the solid or liquid surfaces termed as adsorbent (Crini et al., 2019). An adsorbent is selected on the basis of 
its pore size (surface porosity), high surface area and surface chemistry and the type of pollutant in study (Bhatnagar and Minocha, 2006).

\section{Heavy metal remediation using non-conventional adsorbents}

The usage of commercial activated carbons (CACs) or materials that are being converted into ACs are being restricted due to their expensive operational and manufacturing cost and attention has been shifted towards application of cost effective non-conventional adsorbents (NCAbs). These NCAbs could be of biological origin or from natural materials and can be applied directly in their raw or treated form (Crini et al., 2019). Their application has been increased at an alarming rate in the past few years as they are abundant in nature, are economical ready to use (or can be modified) but their usage is still restricted to pilot scale and needs to be explored more in large field applications (Sangeetha et al., 2017).

Agricultural solid wastes as adsorbents/ nonconventional green adsorbents: In recent years, agricultural solid waste (ASW) has been explored at various levels in their natural or modified form using physico-chemical methods for pollutant removal as former mainly composed of lignin, hemicellulose, lipids, hydrocarbons, carbohydrates, proteins, water that contain various functional groups on their surfaces (Gisi et al., 2016). These functional groups present on their surfaces have charges that can facilitate binding of a particular pollutant by varying $\mathrm{pH}$ levels (Rastogi et al., 2019). Rosales et al. (2019) investigated the role of untreated lime peel and pineapple core wastes in the removal of $\mathrm{Cr}$ (VI) from aqueous solutions with adsorption capacities of 9.20 and $4.99 \mathrm{mg} / \mathrm{g}$ respectively at $\mathrm{pH} 2.01$. In an another recent study conducted using peels of Artocarpus nobilis for the removal of $\mathrm{Ni}$ (II) showed enhanced metal removal efficiency from 50 to 71 to $93 \%$ through optimization processes having $12,048 \mathrm{mg} / \mathrm{kg}$ as maximum adsorption capacity via static and dynamic conditions with Freundlich model as the best fitted adsorption model where regression coefficient has 0.994 value (Priyantha and Kotabewatta, 2019). An efficient adsorption process includes optimization of various factors that can affect an adsorption study such as $\mathrm{pH}$, adsorbent dose, reaction contact time, initial metal concentration, temperature, revolutions per minute (rpm), pressure, etc. which are needed to be identified for the large scale application of adsorption process (Guyo et al., 2017). Biswas et al. (2019) employed central composite design (CCD) for adsorption factors optimization using a novel biochar aliginate composite adsorbent in the removal of $\mathrm{Zn}$ (II) ions. They reported the initial $\mathrm{Zn}(\mathrm{II})$ concentration (43.18 ppm) and adsorbent dose (0.062 g) as most effective factors on account of high $\mathrm{f}$-value which explained maximum adsorption capacity of $120 \mathrm{mg} / \mathrm{g}$ giving 85\% removal efficiency. Though the conversion of agricultural waste residue at nano-scale level provides high surface area but also leads to difficulty in their separation from the study system, therefore, focus has been shifted to utilise them in the dual form where an adsorbent is merged 
with a suitable membrane (Zeng et al., 2016). Hubadillah et al. (2016) explored the efficiency of green ceramic hollow fibre membrane (CHFM) synthesised from rice husk ash (RHA) in removal of $\mathrm{Ni}(\mathrm{II}), \mathrm{Zn}$ (II) and $\mathrm{Pb}(\mathrm{II})$ ions giving $99 \%$ removal rate. The modified CHFM/RHA based dual function material and others might serve as a promising low-cost adsorbent + filtration unit for the removal of noxious heavy metal ions from the aqueous systems.

Industrial by-products as low-cost adsorbents: The processing of substances at industrial level generates huge amount of secondary wastes whose disposal is another problem but these can be utilised as adsorbents in their raw or modified form. For instance, the iron industry during smelting of iron in blast furnace produces slag waste whereas coal industry generates fly ash wastes that can be optimized for heavy metal removal from waste streams. Nguyen and his team assessed the removal efficiency of slag and fly ash wastes in the removal of five metals $(\mathrm{Pb}, \mathrm{Cu}$, $\mathrm{Cd}, \mathrm{Cr}$ and $\mathrm{Zn}$ ) and found the maximum adsorption capacity for $\mathrm{Pb}$ and $\mathrm{Cd}$, when used in multiple metal system at an optimum pH 6.5 (Nguyen et al., 2018). Another mixed metal system study conducted by Ma et al., (2018) reported the maximum adsorption capacities to be 420.17, 680.93, 251.89, and $235.29 \mathrm{mg} / \mathrm{g}$ for $\mathrm{Ni}(\mathrm{II}), \mathrm{Cu}(\mathrm{II}), \mathrm{Zn}(\mathrm{II})$ and $\mathrm{Co}(\mathrm{II})$ respectively using a novel waste product 'calcium silicate powder' as adsorbent obtained during alumina production in coal ash industry. Liu et al. (2017) employed fly ash based granular adsorbent containing zero valent iron (ZVI-GAM) for the removal of $\mathrm{Pb}$ (II) and $\mathrm{Cr}(\mathrm{VI})$ from the aqueous system with 78.13 and $15.70 \mathrm{mg} / \mathrm{g}$ maximum adsorption capacities respectively. Red mud is another waste by-product that is being exploited as an efficient adsorbent. Hydrazine sulphate mixed red mud when incorporated in calcium alginate beads utilised as an excellent adsorbent for $\mathrm{Pb}$ (II) ions removal having $138.6 \mathrm{mg} / \mathrm{g}$ adsorption capacity (Babu et al., 2017). Tsamo et al. (2018) explored the efficiency of low cost raw and hydrocholoric acid treated red mud in the removal of $\mathrm{Cr}(\mathrm{VI}), \mathrm{Cu}(\mathrm{II})$ and $\mathrm{Pb}(\mathrm{II})$. They reported that acid treated red mud had only little affect in removal of $\mathrm{Cr}(\mathrm{VI})$ and $\mathrm{Cu}$ (II) but had increased removal percentage for $\mathrm{Pb}$ (II) (79.365 from $52.083 \mu \mathrm{mol} / \mathrm{g}$ adsorption capacity). Ahsaine et al. (2017) reported the use of sulphuric acid modified sewage sludge for the removal of $\mathrm{Cd}(\mathrm{II})$ ions from aqueous system with adsorption capacity of $56.2 \mathrm{mg} / \mathrm{g}$. A similar study explored the role of thermally (physical activation) modified sewage sludge in the removal of $\mathrm{Cu}(\mathrm{II})$ giving about 73\% removal rate from the synthetic wastewater (Abdel-Aziz et al., 2017). In the recent years, many researchers have worked with industrial wastes as suitable adsorbents for the heavy metal removal.

For instance, iron ore slime (a mining waste) for $\mathrm{Pb}$ (II) and $\mathrm{Hg}$ (II) removal (Sarkar et al., 2017); carboxymethyl-chitosan treated solid sludge biochar for $\mathrm{Pb}$ (II) and $\mathrm{Hg}$ (II) ions (Ifthikar et al., 2018); coal fly ash for $\mathrm{Hg}$ (II) removal (Attari et al., 2017); magnetic 4A-zeolite from red mud for $\mathrm{Al}$ (III), Fe(II), and other metals (Xie et al., 2018). Recently, hollow porous granules (PS-HPGs) were synthesised from industrial wastes of polysulphone hollow fibre membranes when incorporated with nano-range polydopamine (PD) served as efficient 
adsorbent for the $80 \%$ removal of $\mathrm{Cu}(\mathrm{II})$ ions and for $\mathrm{Zn}(\mathrm{II})$ and $\mathrm{Ni}$ (II) ions after certain modifications (Posati et al., 2019).

Natural materials: It is usually advocated that mesoporous adsorbents derived from natural materials are good candidates for the heavy metal removal study as these provide large surface activity due to large surface area and uniform large pore size. Mesoporous silica materials (MSMs) derived from MCM41 type was investigatd in the removal of $\mathrm{Cu}(\mathrm{II}), \mathrm{Cd}(\mathrm{II})$ and $\mathrm{Pb}(\mathrm{II})$ with adsorption capacities around $36.3,32.3$ and $58.5 \mathrm{mg} / \mathrm{g}$ in the $\mathrm{pH}$ range 5-7 (Zhu et al., 2017). Vojoudi et al. (2017) evaluated the efficiency of magnetic mesoporous silica as nanoadsorbent for the removal of $\mathrm{Pb}(\mathrm{II})$ and $\mathrm{Hg}$ (II) ions in batch study leading to 303.03 and $256.41 \mathrm{mg} / \mathrm{g}$ adsorption capacities respectively.

Microbial bioadsorbents: The utilization of microorganisms in the eradication of toxic pollutants from contaminated environment is known as bioremediation. Their inbuilt biosorptive or bioaccumulative mechanistic ability (Javanbakht et al., 2014) helps them to tolerate heavy metal toxicity that can be employed in many ways such as absorption, adsorption, oxidation, etc. in pollutant removal or in restoration of original environment (Rajendran et al., 2003). Also, these microorganisms either bacteria, fungi or alga are being exploited in their live as well as dead form that makes them as potential biosorbing agents for the sequestration of heavy metal ions from the aqueous environments (Ayangbenro and Babalola, 2017). Jaiswal et al. (2018) used alginate beads immobilized with fungal biomass as biosorbing material in the removal of As at $\mathrm{pH} 6$ and found the adsorption capacity of about $59.5 \mathrm{mg} / \mathrm{g}$. The potential of dried Gelidium amansii (marine alga) biomass in free and immobilized form was assessed for the removal of $\mathrm{Pb}$ (II) leading to $100 \%$ removal percentage at $\mathrm{pH} 4.5$ (El-Naggar et al., 2018). Jin et al. (2017) investigated the potential of bacterial cellulose pellicles modified with polyethyleneimine in the removal of $\mathrm{Cu}$ (II) and $\mathrm{Pb}$ (II) ions with maximum adsorption capacities to be 148 and $141 \mathrm{mg} / \mathrm{g}$ respectively. Microorganisms are being used not only as whole in live or dead form as adsorbents but their secretions are also explored as suitable adsorbents for the removal of toxic metal ions from waste streams. Castro et al. (2018) explored the efficiency of biogenic (bacterial) iron compounds mainly siderite and magnetite as adsorbent in the removal of $\mathrm{Cu}, \mathrm{Zn}, \mathrm{As}$, and $\mathrm{Cr}$ and reported higher removal percentage for As in single and bimetal system (As-Cu). Li and Zhou (2018) used heavy metal resistant immobilized Brevibacterium as bioadsorbent for the removal of $\mathrm{Pb}$ and $\mathrm{Cd}$ having 114.36 and $82.12 \mathrm{mg} / \mathrm{g}$ maximum adsorption capacity. A brief overview of various non-conventional adsorbents has been summarized in Table 3.

Nanoadsorbents/nanocomposites: The applicability of adsorbents that are carbon-based or metal oxide and metal organic frameworks (MOFs), zeolites in the nano-range has been increased in the recent years due to their large surface area and high surface chemistry (Nasir et al., 2019). Zanin et al. (2016) assessed the role of natural clinoptilolite zeolite (CL) as adsorbent in the 
Table 3. Explains various examples of non-conventional adsorbents, target heavy metal ion(s) and their adsorption efficiency.

\begin{tabular}{|c|c|c|c|c|c|}
\hline $\begin{array}{l}\text { Non-conventional } \\
\text { adsorbent type }\end{array}$ & Example & $\begin{array}{l}\text { Target } \\
\text { heavy } \\
\text { metal } \\
\text { ion(s) }\end{array}$ & $\mathrm{pH}$ & $\begin{array}{l}\text { Adsorption } \\
\text { capacity } \\
(\mathrm{mg} / \mathrm{g})\end{array}$ & References \\
\hline $\begin{array}{l}\text { Nanocomposites/ } \\
\text { Biocomposites }\end{array}$ & $\begin{array}{l}\text { Chitosan-boehmite } \\
\text { desiccant composite }\end{array}$ & $\begin{array}{l}\mathrm{Pb}(\mathrm{II}), \mathrm{Cd} \\
\text { (II), } \mathrm{Hg}(\mathrm{II})\end{array}$ & $\begin{array}{l}6-7(\mathrm{~Pb}(\mathrm{II}), \mathrm{Cd} \\
\text { (II) \& } 10(\mathrm{Hg} \\
\text { (II) }\end{array}$ & $\begin{array}{l}98.84,99.54, \\
74.98\end{array}$ & $\begin{array}{l}\text { Rajamani et } \\
\text { al. (2019) }\end{array}$ \\
\hline $\begin{array}{l}\text { Nanocomposites/ } \\
\text { Biocomposites }\end{array}$ & $\begin{array}{l}\text { Cellulose } \\
\text { biocomposite sponge }\end{array}$ & $\mathrm{Hg}(\mathrm{II})$ & 5.5 & 495 & $\begin{array}{l}\text { Zhang et al. } \\
\text { (2019) }\end{array}$ \\
\hline $\begin{array}{l}\text { Nanocomposites/ } \\
\text { Biocomposites }\end{array}$ & Fe3O4@BHPS & $\begin{array}{l}\mathrm{Pb}(\mathrm{II}), \mathrm{Cd} \\
\text { (II) }\end{array}$ & $5.5,7.1$ & $186.2,125$ & $\begin{array}{l}\text { Alqadami et } \\
\text { al. (2019) }\end{array}$ \\
\hline $\begin{array}{l}\text { Nanocomposites/ } \\
\text { Biocomposites }\end{array}$ & $\begin{array}{l}\text { SiO2@chitosan } \\
\text { composite }\end{array}$ & $\begin{array}{l}\mathrm{As}(\mathrm{V}), \mathrm{Hg} \\
\text { (II) }\end{array}$ & $6-7$ & 198.6, 204.1 & $\begin{array}{l}\text { Liu et al. } \\
\text { (2019) }\end{array}$ \\
\hline $\begin{array}{l}\text { Agro-Industrial } \\
\text { wastes }\end{array}$ & $\begin{array}{l}\text { Zeolite from JIS type } \\
\text { II fly ash }\end{array}$ & $\begin{array}{l}\mathrm{Hg}(\mathrm{II}), \mathrm{Pb} \\
\text { (II) }\end{array}$ & 5 & $30.8,40.5$ & $\begin{array}{l}\text { Kobayashi et } \\
\text { al. (2020) }\end{array}$ \\
\hline $\begin{array}{l}\text { Agro-Industrial } \\
\text { wastes }\end{array}$ & $\begin{array}{l}\text { Carboxymethylated } \\
\text { softwood kraft pulp } \\
\text { cellulose fibers }\end{array}$ & $\begin{array}{l}\mathrm{Cu}(\mathrm{II}), \mathrm{Ni} \\
(\mathrm{II})\end{array}$ & 6 & $16.90,11.63$ & $\begin{array}{l}\text { Wang et al. } \\
\text { (2019) }\end{array}$ \\
\hline $\begin{array}{l}\text { Agro-Industrial } \\
\text { wastes }\end{array}$ & Lemon peel & $\mathrm{Cu}(\mathrm{II})$ & 3 & 13.2 & $\begin{array}{l}\text { Meseldzija et } \\
\text { al. (2019) }\end{array}$ \\
\hline $\begin{array}{l}\text { Agro-Industrial } \\
\text { wastes }\end{array}$ & $\begin{array}{l}\text { Acid modified } \\
\text { Biochar from rice } \\
\text { husk }\end{array}$ & $\mathrm{Cr}(\mathrm{VI})$ & 2 & $4536 \mu \mathrm{g} / \mathrm{g}$ & $\begin{array}{l}\text { Sarkar et al. } \\
\text { (2019) }\end{array}$ \\
\hline $\begin{array}{l}\text { Microbe based/ } \\
\text { Microbial } \\
\text { bioadsorbent }\end{array}$ & $\begin{array}{l}\text { Bacterial cellulose/ } \\
\text { attapulgite magnetic } \\
\text { composites }\end{array}$ & $\begin{array}{l}\mathrm{Cu}(\mathrm{II}), \mathrm{Cr} \\
\text { (VI), } \mathrm{Pb} \\
\text { (II) }\end{array}$ & 5.5 & $\begin{array}{l}70.5,91.0 \\
67.8\end{array}$ & $\begin{array}{l}\text { Chen et al. } \\
(2020)\end{array}$ \\
\hline $\begin{array}{l}\text { Microbe based/ } \\
\text { Microbial } \\
\text { bioadsorbent }\end{array}$ & $\begin{array}{l}\text { Graphene oxide } \\
\text { based bacterial } \\
\text { cellulose }\end{array}$ & $\begin{array}{l}\mathrm{Cu}(\mathrm{II}), \mathrm{Cd} \\
\text { (II), } \mathrm{Pb} \text { (II) }\end{array}$ & $5-5.5$ & $\begin{array}{l}91.32,148.37, \\
160.0\end{array}$ & $\begin{array}{l}\text { Luo et al. } \\
(2020)\end{array}$ \\
\hline $\begin{array}{l}\text { Microbe based/ } \\
\text { Microbial } \\
\text { bioadsorbent }\end{array}$ & $\begin{array}{l}\text { Pseudomonas sp. strain } \\
375 \text { (live and dead } \\
\text { form) }\end{array}$ & $\mathrm{Cd}(\mathrm{II})$ & 7 & $92.59,63.29$ & $\begin{array}{l}\text { Xu et al. } \\
(2020)\end{array}$ \\
\hline $\begin{array}{l}\text { Microbe based/ } \\
\text { Microbial } \\
\text { bioadsorbent }\end{array}$ & Penicillium sp. & $\mathrm{Pb}(\mathrm{II})$ & 5.5 & 0.16 & $\begin{array}{l}\text { Rastogi et al. } \\
\text { (2019) }\end{array}$ \\
\hline $\begin{array}{l}\text { Microbe based/ } \\
\text { Microbial } \\
\text { bioadsorbent }\end{array}$ & $\begin{array}{l}\text { Pseudomonas sp. strain } \\
\text { DC-B3 }\end{array}$ & $\begin{array}{l}\mathrm{Cu}(\mathrm{II}), \mathrm{Cd} \\
\text { (II) }\end{array}$ & 6 & $12.6,26.5$ & $\begin{array}{l}\text { Liang et al. } \\
\text { (2019) }\end{array}$ \\
\hline $\begin{array}{l}\text { Industrial } \\
\text { byproducts }\end{array}$ & $\begin{array}{l}\text { Graphene oxide } \\
\text { based newspaper } \\
\text { wastes }\end{array}$ & $\begin{array}{l}\mathrm{Pb}(\mathrm{II}), \mathrm{Ni} \\
(\mathrm{II}), \mathrm{Cd}(\mathrm{II})\end{array}$ & & $\begin{array}{l}75.41,29.04, \\
31.35\end{array}$ & $\begin{array}{l}\text { Chen et al. } \\
(2020)\end{array}$ \\
\hline $\begin{array}{l}\text { Industrial } \\
\text { byproducts }\end{array}$ & $\begin{array}{l}\text { Incinerated sewage } \\
\text { sludge ash }\end{array}$ & $\mathrm{Pb}(\mathrm{II})$ & 6 & 62.42 & $\begin{array}{l}\text { Wang et al. } \\
\text { (2019) }\end{array}$ \\
\hline Natural materials & $\begin{array}{l}\text { Magnetic } \mathrm{Fe}_{3} \mathrm{O}_{4-} \\
\text { chitosan@bentonite }\end{array}$ & $\mathrm{Cr}(\mathrm{VI})$ & 2 & 62.1 & $\begin{array}{l}\text { Feng et al. } \\
(2019)\end{array}$ \\
\hline Natural materials & $\begin{array}{l}\text { Clay minerals } \\
\text { (bentonite, volcanic } \\
\text { ash soil, red soil) }\end{array}$ & $\begin{array}{l}\mathrm{Ni}(\mathrm{II}), \mathrm{Cu} \\
(\mathrm{II}), \mathrm{Zn}(\mathrm{II})\end{array}$ & - & $\begin{array}{l}99.9,99.9 \\
89.2\end{array}$ & $\begin{array}{l}\text { Esmaeili et } \\
\text { al. (2019) }\end{array}$ \\
\hline
\end{tabular}


removal of heavy metals from graphic industry with removal efficiency up to $95.4,96.0$ and $85.1 \%$ for $\mathrm{Fe}, \mathrm{Cu}$ and $\mathrm{Cr}$ respectively. But these nanocomposites tend to agglomerate that results in reduction of surface area, also gives rise to recyclability and environmental issues due to which these are utilized in hybrid composite forms (Bajpai et al., 2019). Shahat et al. (2015) explored the role of an organic nano-ligand N, N'-di (3-carboxysalicylidene)-3, 4-diamino-5-hydroxypyrazole that was anchored using building block approach on mesoporous silica and termed as facial adsorbent for the removal of $\mathrm{Co}(\mathrm{II})$ ions from their aqueous solutions and reported maximum adsorption capacity of $157.73 \mathrm{mg} / \mathrm{g}$ at higher $\mathrm{pH}$ values. In an another similar study conducted by Vafaeifard et al. (2019) analysed the potential of nanostructured flowerlike $\mathrm{Mg}(\mathrm{OH})_{2}$ that was assembled on granular polyurethane as nanoadsorbent for the removal of $\mathrm{Cu}$ (II), $\mathrm{Cd}$ (II) and $\mathrm{Pb}$ (II) with astonishing 472, 1050 and $1293 \mathrm{mg} / \mathrm{g}$ adsorption capacities respectively in batch processes and up to $184 \mathrm{mg} / \mathrm{g}$ adsorption capacity for $\mathrm{Cu}(\mathrm{II})$ in a continuous-flow column study. Bio-nanocomposites are advantageous as they impart biodegradability, biocompatibility and antimicrobial activity (Bajpai et al., 2019). Souza et al. (2018) investigated the potential of Malpighia emarginata D.C. seed fibers microparticles (Me-SFMp) as bioadsorbent and found metal removal efficiencies up to $81,84.2,86.8$, and $95.1 \%$ for $\mathrm{Ni}, \mathrm{Cu}, \mathrm{Pb}$ and $\mathrm{Cr}$ respectively while $100 \%$ for both $\mathrm{Zn}$ and $\mathrm{Cd}$. An efficiency of a novel chitosan-iron (oxyhydr) oxide composite known as chitosan goethite bionanocomposite (CGB) in the form of beads was explored and found to remove $\mathrm{As}(\mathrm{V})$ more than $\mathrm{As}(\mathrm{III})$ from aqueous solutions through diffusion-adsorption mechanism (He et al., 2016). Ahmad and Mirza (2015) evaluated the role of methionine modified bentonite/alginate (Meth-bent/Alg) in the removal of $\mathrm{Pb}(\mathrm{II})$ and $\mathrm{Cd}(\mathrm{II})$ at $\mathrm{pH} 5$ and 4 respectively with 30.86 and $217.39 \mathrm{mg} / \mathrm{g}$ adsorption capacities at $303 \mathrm{~K}$ respectively.

Polymer-layered silicate nanocomposites (PLSNs) and polymer-functionalized nanocomposites (PFNCs) are emerging as superior nonconventional nanocomposites as these provide stability, better reinforcement rate at less than $10 \%$, resistance against many solvents, temperature, ions and have mechanical strength, diverse functional groups on their surfaces leading to strong specific bindings to metal ions or any other pollutant (Ucankus et al., 2018; Bajpai et al., 2019).

\section{Bacterial bio-surfactants}

The unfavourable environment triggers a stress response in microorganisms such as bacteria and fungi to produce various secondary metabolites to cope up with those antagonistic conditions. Bacterial bio-surfactants are one such compound that has proved their existence fruitful for the bioremediation of inorganic contaminants particularly heavy metals (Akbari et al., 2018). Table 4 explains about different class of biosurfactant and their types along with latest metal remediation potential. Some of the common properties that make a bio-surfactant molecule to be preferred over chemical surfactants are surface and interfacial tension reduction ability, highly tolerant to 
Table 4. Bio-surfactant class/type producing microorganism and their action on metal ion type with removal method (adapted from Sarubbo et al., 2015)

\begin{tabular}{|c|c|c|c|c|c|}
\hline $\begin{array}{l}\text { Bio- } \\
\text { surfactant } \\
\text { class }\end{array}$ & Bio-surfactant type & Microorganism & $\begin{array}{l}\text { Target } \\
\text { heavy } \\
\text { met al }\end{array}$ & $\begin{array}{l}\text { Remediation } \\
\text { method }\end{array}$ & References \\
\hline \multirow[t]{4}{*}{ Glycolipids } & Rhamnolipids & $\begin{array}{l}\text { Psuedomonas sp., } \\
\text { Shewanella } \\
\text { sp.BS4, } \\
\text { Marinobacter sp. }\end{array}$ & $\begin{array}{l}\mathrm{Cd}(\mathrm{II}), \\
\mathrm{Ni}(\mathrm{II}), \\
\mathrm{Cu}(\mathrm{II})\end{array}$ & Washing & $\begin{array}{l}\text { Shen et al. } \\
\text { (2019); Lee and } \\
\text { Kim (2019) }\end{array}$ \\
\hline & Sophorolipids & $\begin{array}{l}\text { Candida sp. } \\
\text { AH62, } \\
\text { C. bombicola } \\
\text { ATCC } 22214\end{array}$ & $\begin{array}{l}\mathrm{Cu}(\mathrm{II}) \\
\mathrm{Zn}(\mathrm{II})\end{array}$ & Washing & $\begin{array}{l}\text { Da Rocha Jun- } \\
\text { ior et al. (2019) }\end{array}$ \\
\hline & Trehalolipids & Rhodococcus sp. & $\mathrm{Co}(\mathrm{II})$ & Washing & $\begin{array}{l}\text { Narimannejad } \\
\text { et al. (2019) }\end{array}$ \\
\hline & $\begin{array}{l}\text { Mannosylerythritol } \\
\text { lipids }\end{array}$ & $\begin{array}{l}\text { Ustilago sp., } \\
\text { Moesziomyces } \\
\text { antarcticus }\end{array}$ & - & - & $\begin{array}{l}\text { Bakur et al. } \\
\text { (2019) }\end{array}$ \\
\hline \multirow{4}{*}{$\begin{array}{l}\text { Lipopeptides } \\
\text { and Lipopro- } \\
\text { teins }\end{array}$} & Lichenysin & Bacillus sp. & $\begin{array}{l}\mathrm{Cu}(\mathrm{II}) \\
\mathrm{Pb}(\mathrm{II})\end{array}$ & Washing & $\begin{array}{l}\text { Saleem et al. } \\
\text { (2019) }\end{array}$ \\
\hline & Surfactin & $\begin{array}{l}\text { Bacillus subtilis, } \\
\text { paenibacillus sp. } \\
\text { D9 }\end{array}$ & $\begin{array}{l}\mathrm{Pb}(\mathrm{II}), \\
\mathrm{Cu}(\mathrm{II}), \\
\mathrm{Zn}(\mathrm{II}), \\
\mathrm{Fe}(\mathrm{II}), \\
\mathrm{Ca}(\mathrm{II}), \\
\mathrm{Ni}(\mathrm{II}), \\
\mathrm{Cr}(\mathrm{VI}), \\
\mathrm{Cd}(\mathrm{II})\end{array}$ & Washing & $\begin{array}{l}\text { Jimoh and Lin } \\
\text { (2020); Hisham } \\
\text { et al. (2019) }\end{array}$ \\
\hline & $\begin{array}{l}\text { Carbohydrate-lipid } \\
\text {-protein }\end{array}$ & P. fluorescens & $\mathrm{Cr}(\mathrm{VI})$ & Washing & $\begin{array}{l}\text { Kalaimurugan } \\
\text { et al. (2019) }\end{array}$ \\
\hline & $\begin{array}{l}\text { Mannan-lipid- } \\
\text { protein }\end{array}$ & C. tropicalis & $\begin{array}{l}\mathrm{Cu}(\mathrm{II}), \\
\mathrm{Zn}(\mathrm{II}), \\
\mathrm{Pb}(\mathrm{II}), \\
\mathrm{Cd}(\mathrm{II})\end{array}$ & Biosorption & $\begin{array}{l}\text { Mbachu et al. } \\
\text { (2019) }\end{array}$ \\
\hline \multirow[t]{2}{*}{$\begin{array}{l}\text { Particulate } \\
\text { surfactants }\end{array}$} & Vesicles & $\begin{array}{l}\text { Pseudomonas } \\
\text { marginalis }\end{array}$ & $\mathrm{Cd}(\mathrm{II})$ & $\begin{array}{l}\text { Plant growth } \\
\text { promoting } \\
\text { phytoremediation }\end{array}$ & $\begin{array}{l}\text { Shahid et al. } \\
\text { (2019) }\end{array}$ \\
\hline & $\begin{array}{l}\text { Whole microbial } \\
\text { cells }\end{array}$ & Cyanobacteria & $\begin{array}{l}\mathrm{Cd}(\mathrm{II}), \\
\mathrm{Cu}(\mathrm{II}) \\
\mathrm{Pb}(\mathrm{II})\end{array}$ & Biosorption & $\begin{array}{l}\text { Delneuville et } \\
\text { al. (2019) }\end{array}$ \\
\hline
\end{tabular}


$\mathrm{pH}$, salinity, temperature moderations, biodegradability and biocompatibility, less toxic, specificity and emulsification capacity (Usman et al., 2016). There has been done much work in the recent years that has proved the role of bio-surfactant producing bacteria in the bioremediation of heavy metal contaminated soils. Chen et al. (2017) assessed the potential of biosurfactant rhamnolipid in washing of heavy metal ions from river sediment. A dose of $0.8 \%$ rhamnolipid removed $\mathrm{Cu}(80.21 \%), \mathrm{Cd}(86.87 \%), \mathrm{Pb}(63.54 \%)$ and $\mathrm{Cr}(47.85 \%)$ after $12 \mathrm{~h}$ at $\mathrm{pH}$ 7.0. They emphasised that the efficiency of washing depended on initial heavy metal ion speciation, rhamnolipid concentration, washing time, liquid/solid ratio and $\mathrm{pH}$. In an another experimental setup, researchers modified the conventional electro-kinetic treatment with biodegradable rhamnolipid and complexing agent Tetrasodium of N, N-bis (carboxymethyl) glutamic acid (GLDA) in heavy metal removal from sewage sludge and showed significantly higher removal percentages of $70.6 \pm 3.41 \%, 82.2 \pm 5.21 \%, 89.0 \pm 3.34 \%, 60.0 \pm 4.67 \%, 88.4 \pm 4.43 \%$ and $70.0 \pm 3.51 \%$ for $\mathrm{Cu}, \mathrm{Zn}, \mathrm{Cr}, \mathrm{Pb}, \mathrm{Ni}$ and $\mathrm{Mn}$ respectively (Tang et al., 2017). Similar studies performed by Yang et al. (2018) proposed an efficient bioleaching technique using bio-surfactants from Burkholderia sp. Z-90 in combination with flocculation by poly aluminium chloride (PAC) as a cost effective, environment-friendly remediation model for severely heavy metal contaminated soils. Their results showed removal efficieny of $\mathrm{Zn}, \mathrm{Pb}, \mathrm{Mn}, \mathrm{Cd}, \mathrm{Cu}$ and As upto 44.0, 32.5, 52.2, 37.7, 24.1 and $31.6 \%$ respectively at 1:20 (w/v) soil liquid ratio for 5 days which were found to be more efficient than that by $0.1 \%$ of rhamnolipid. The bioremediation potential of bacterial bio-surfactants pertains to their high biodegradable nature, low toxicity, multi-functionality, environmental compatibility and economical production which make them an excellent alternative over various synthetic surfactants that are available in the market (Akbari et al., 2018).

\section{Bio-surfactant mediated methods for the management of heavy metal contaminated soils}

There are various methods available for remediation of heavy metal contaminated soils. The different in-situ approaches include surface capping, encapsulation, electro-kinetic extraction, soil flushing, chemical immobilization, bioremediation and phytoremediation and ex-situ methods are landfilling, solidification, soil washing and vitrification (Liu et al., 2018; Kumar et al., 2019) but bio-surfactant producing bacteria manages this high density metal pollution through soil washing and soil flushing methods (Ayangbenro and Babalola, 2018).

Soil flushing: This is an in-situ approach where a small quantity of biopolymer is injected in the contaminated soil in a cement mixer that has drain pipes or trenches for the introduction and collection of biopolymer solution into or out of the soil. This surfactant based flushing technique was first demonstrated by Pankow and Cherry (1996). The complex thus formed due to the strong bonding between anionic bio-surfactants and cationic heavy metal ions is flushed out of the mixer as it easily separates out from soil matrix and soil gets deposited back into it. The metal 
-biopolymer complex precipitates out the biopolymer leaving behind the metal ion (Mulligan et al., 2001; Ayangbenro and Babalola, 2018). Wang and Mulligan (2009) did column experiments to assess the potential of rhamnolipid JBR425 and found enhanced removal of $\mathrm{As}(\mathrm{V}), \mathrm{Cu}, \mathrm{Zn}$ and $\mathrm{Pb}$ using $0.1 \%$ rhamnolipid with 70 pore-volumes flushing operation under alkaline conditions. The desorption of adsorbed metal ions from the adsorbent matrix can be enhanced by flushing the matrix with bio-surfactant-foam solution as demonstrated by Haryanto and Chang (2015) in removal of adsorbed $\mathrm{Cu}(\mathrm{II})$ ions from sand-packed columns.

Soil washing: This ex-situ remediation technology eliminates obnoxious heavy metal ions from the soil through washing and scrubbing of the soil with bio-surfactant solution (Sarubbo et al., 2015). Diaz et al., (2015) assessed Fe and Zn removal from contaminated soil using alternate cycles of bioleaching with oxidising bacteria (Acidithiobacillus thiooxidans and Acidithiobacillus ferrooxidans) and washing with rhamnolipid solution and found the combined strategy to enhance removal percentage up to $36 \%$ for $\mathrm{Fe}$ and $63 \%$ to $70 \%$ for $\mathrm{Zn}$ than alone treatments. The high percentage of toxic contaminants in the soil and sludge may obstruct nutrient recycling and land usage. The washing of soil sediments with bio-surfactant solution could provide a suitable bioremediation alternative that can enhance mineral availability and land application. Tang et al. (2019) showed increased metal mobility, binding ability and removal efficiency of $\mathrm{Cu}, \mathrm{Zn}, \mathrm{Cr}, \mathrm{Ni}$ and $\mathrm{Mn}$ up to $62 \%, 74 \%, 60 \%, 68 \%$ and $64 \%$ respectively than $\mathrm{Pb}$ (only $15 \%$ ) using rhamnolipids and saponins in multiple washing steps.

\section{Mechanism of heavy metal removal by bio-surfactants}

The working strategy for BS mediated HM remediation is based on Le Chatelier's principle either through precipitation or adsorption. BSs are capable of forming complexes with free metal ions present in the solution leading to desorption of metal ions (Wu et al., 2017) from the solution phase. Qi et al. (2018) assessed the removal of $\mathrm{Pb}(\mathrm{II})$ and $\mathrm{Cd}(\mathrm{II})$ from soil by utilising sophorolipids of Starmerella bombicola CGMCC 1576 and reported about 95 and $52 \%$ of $\mathrm{Cd}$ and $\mathrm{Pb}$ removal percentage respectively by complexation mechanism in soil washing system. Secondly, as BSs can reduce the surface and interfacial tension of the medium, these get accumulated in the form of micelles on the solid/solution interface and bind the metal ions on themselves (Ayangbenro and Babalola, 2018). According to Tortora et al. (2016) the metal-BS complex or metal-micelle complex can be taken out from the system using micellar enhanced microfiltration (MEMF) or micellar enhanced ultrafiltration (MEUF). The efficiency of BSs depends on their size, class type, charge and structure that facilitates or determines their interaction with the sorbed metal on the soil (solid) surfaces (Wan et al., 2017), also their translocation through soil pores on to the sorbed metal ions. Alternatively, the type of soil, its structure, contamination level and duration, $\mathrm{pH}$, cation exchange capacity (CEC) and soil particle pore size also affects BS ability to remove metal ion from their surfaces or depth (Xue et al., 2018; Pourfadakari et al., 2019). 


\section{Surfactant/bio-surfactant modified low cost adsorbents (LCAs)}

Chemically originated or biologically secreted surfactants are amphillic molecules having both hydrophilic and hydrophobic ends and are widely used in the HM remediation process where biological surfactants are preferred over chemically synthesised surfactants as the former have low toxicity, specificity, biodegradable nature, etc (Hailu et al., 2018). The natural materials such as zeolites and clays are known to be used as adsorbents in the HM removal process whose efficiency can be intensified by using acids or alkalies (Jimenez-Castaneda and Medina, 2017). In recent years, many studies have been conducted where these amphillic molecules when incorporated on such zeolites or clay materials, has increased the efficiency of the latter in the remediation process through ion exchange mechanism (Jimenez-Castaneda and medina, 2017; Li et al., 2007). Tran et al. (2018) explored the efficiency of cationic surfactant 'hexa-decyl-tri-methylammonium' (HDTMA) modified organo-zeolite (Na-H-zeolite) in the removal of $\mathrm{Pb}, \mathrm{Cu}, \mathrm{Ni}$ and other organic pollutants. In a similar study, cationic surfactant 'hexa-decyl-tri-methyl-ammonium -bromide' C16 and zwitterionic surfactant 'hexa-decyl-di-methyl(3-sulphonatopropyl) ammonium' Z16 were applied on organo-montmorillonites for the removal of $\mathrm{Cu}$ (II) ions from the aqueous system (Ma et al., 2016).

\section{Conclusion and recommendations}

The application of non-conventional adsorbents and bacterial surfactants for the removal of heavy metal is gaining attention, owing to their easy availability, biodegradable nature and low toxicity. The agro-industrial wastes can be applied directly or in modified form for the treatment process and also can be used as substrates for the production of bio-surfactants making the remediation process more economical. The present chapter furnishes that this integrated approach can open up a novel aspect for remediation of heavy metal ions from the environment. Henceforth, more research is needed to be carried out to find new materials and novel bio-surfactants for environmental sustainability.

\section{References}

Abdel-Aziz, M.H., Bassyouni, M., Soliman, M.F., Gutub, S.A. and Magram, S.F. (2017). Removal of heavy metals from wastewater using thermally treated sewage sludge adsorbent without chemical activation. Journal of Materials and Environmental Science, 8(5): 1737-1747.

Ahmad, R. and Mirza, A. (2015). Sequestration of heavy metal ions by Methionine modified bentonite/Alginate (Meth-bent/ Alg): A bionanocomposite. Groundwater for Sustainable Development, 1(1-2): 50-58. https://doi.org/10.1016/ j.gsd.2015.11.003

Ahsaine, H.A., Zbair, M. and El Haouti, R. (2017). Mesoporous treated sewage sludge as outstanding low-cost adsorbent for 
cadmium removal. Desalination and Water Treatment, 85: 330-338. https://doi.org/10.5004/dwt.2017.21310

Akbari, S., Abdurahman, N.H., Yunus, R.M., Fayaz, F. and Alara, O.R. (2018). Biosurfactants - a new frontier for social and environmental safety: a mini review. Biotechnology Research and Innovation, 2: 81-90. https://doi.org/10.1016/ j.biori.2018.09.001

Alak, G., Parlak, V., Aslan, M.E., Ucar, A., Atamanalp, M. and Turkez, H. (2019). Borax supplementation alleviates hematotoxicity and DNA damage in rainbow trout (Oncorhynchus mykiss) exposed to copper. Biological Trace Element Research, 187(2): 536-542. https:// doi.org/10.1007/s12011-018-1399-6

Alqadami, A.A., Khan, M.A., Alothman, Z.A., Alsohaimi, I.H., Siddiqui, M.R. and Ghfar, A.A. (2019). U.S. Patent No. 10,245,576. Washington, DC: U.S. Patent and Trademark Office.

Attari, M., Bukhari, S.S., Kazemian, H. and Rohani, S. (2017). A low-cost adsorbent from coal fly ash for mercury removal from industrial wastewater. Journal of Environmental Chemical Engineering, 5(1): 391-399. https://doi.org/10.1016/ j.jece.2016.12.014

Ayangbenro, A. and Babalola, O. (2018). Metal (loid) bioremediation: strategies employed by microbial polymers. Sustainability, 10(9): 3028. https://doi.org/10.3390/su10093028

Ayangbenro, A.S. and Babalola, O.O. (2017). A new strategy for heavy metal polluted environments: a review of microbial biosorbents. International Journal of Environmental Research and Public Health, 14(1): 94. https://doi.org/10.3390/ ijerph14010094

Bajpai, A., Sharma, M. and Gond, L. (2019). Nanocomposites for Environmental Pollution Remediation. Sustainable Polymer Composites and Nanocomposites, Springer, Cham, pp. 1407-1440.

Bakur, A., Niu, Y., Kuang, H. and Chen, Q. (2019). Synthesis of gold nanoparticles derived from mannosylerythritol lipid and evaluation of their bioactivities. AMB Express, 9(1): 62. https:// doi.org/10.1186/s13568-019-0785-6

Bhatnagar, A. and Minocha, A.K. (2006). Conventional and non-conventional adsorbents for removal of pollutants from water -A review. Indian Journal of Chemical Technology, 13: 203-217.

Biswas, S., Bal, M., Behera, S.K., Sen, T.K. and Meikap, B.C. (2019). Process optimization study of Zn2+ adsorption on biocharalginate composite adsorbent by response surface methodology (RSM). Water, 11(2): 325. https://doi.org/10.3390/ w11020325

Bora, A.J. and Dutta, R.K. (2019). Removal of metals ( $\mathrm{Pb}, \mathrm{Cd}, \mathrm{Cu}, \mathrm{Cr}, \mathrm{Ni}$, and $\mathrm{Co}$ ) from drinking water by oxidationcoagulation-absorption at optimized pH. Journal of Water Process Engineering, 31: 100839. https://doi.org/10.1016/ j.jwpe.2019.100839

Calvert, J.G. (1990). Glossary of atmospheric chemistry terms (Recommendations 1990). Pure and Applied Chemistry, 62(11): 2167-2219.

Cariccio, V.L., Samà, A., Bramanti, P. and Mazzon, E. (2019). Mercury involvement in neuronal damage and in neurodegenerative diseases. Biological Trace Element Research, 187(2): 341-356. https:// doi.org/10.1007/s12011-018-1380-4

Castro, L., Blázquez, M.L., González, F., Muñoz, J.A. and Ballester, A. (2018). Heavy metal adsorption using biogenic iron compounds. Hydrometallurgy, 179: 44-51. https://doi.org/10.1016/j.hydromet.2018.05.029

Chen, W., Qu, Y., Xu, Z., He, F., Chen, Z., Huang, S. and Li, Y. (2017). Heavy metal (Cu, Cd, Pb, Cr) washing from river sediment using biosurfactant rhamnolipid. Environmental Science and Pollution Research, 24(19): 16344-16350. https:// doi.org/10.1007/s11356-017-9272-2

Chen, X., Cui, J., Xu, X., Sun, B., Zhang, L., Dong, W. and Sun, D. (2020). Bacterial cellulose/attapulgite magnetic composites as an efficient adsorbent for heavy metal ions and dye treatment. Carbohydrate Polymers, 229: 115512. https:// doi.org/10.1016/j.carbpol.2019.115512

Chung, K.W., Dhillon, P., Huang, S., Sheng, X., Shrestha, R., Qiu, C., Kaufman, B.A., Park, J., Pei, L., Baur, J., Palmer, M. and Susztak, K. (2019). Mitochondrial damage and activation of the STING pathway lead to renal inflammation and fibrosis. Cell Metabolism, 30(4): 784-799. https://doi.org/10.1016/j.cmet.2019.08.003

Crini, G. and Lichtfouse, E. (2019). Advantages and disadvantages of techniques used for wastewater treatment. Environmental Chemistry Letters, 17(1): 145-155. https://doi.org/10.1007/s10311-018-0785-9

da Rocha Junior, R.B., Meira, H.M., Almeida, D.G., Rufino, R.D., Luna, J.M., Santos, V.A. and Sarubbo, L.A. (2019). Applica- 
tion of a low-cost biosurfactant in heavy metal remediation processes. Biodegradation, 30(4): 215-233. https:// doi.org/10.1007/s10532-018-9833-1

Das, S.C. and Al-Naemi, H.A. (2019). Cadmium Toxicity: Oxidative Stress, Inflammation and Tissue Injury. Occupational Diseases and Environmental Medicine, 7(4): 144-163. https://doi.org/10.4236/odem.2019.74012

De Gisi, S., Lofrano, G., Grassi, M. and Notarnicola, M. (2016). Characteristics and adsorption capacities of low-cost sorbents for wastewater treatment: A review. Sustainable Materials and Technologies, 9: 10-40. https://doi.org/10.1016/ j.susmat.2016.06.002

Delil, A.D., Köleli, N., Dağhan, H. and Bahçeci, G. (2020). Recovery of heavy metals from canola (Brassica napus) and soybean (Glycine max) biomasses using electrochemical process. Environmental Technology E Innovation, 17: 100559. https:// doi.org/10.1016/j.eti.2019.100559

Delneuville, C., Danloy, E.P., Wang, L. and Su, B.L. (2019). Single cyanobacteria@ silica porous microcapsules via a sol-gel layer by layer for heavy-metal remediation. Journal of Sol-Gel Science and Technology, 89(1): 244-254. https:// doi.org/10.1007/s10971-018-4687-x

Deuel, L.E. and Holliday, G.H. (1994). Soil remediation for petroleum extraction industry. PennWell Books.

Dias, Y.N., Souza, E.S., da Costa, H.S.C., Melo, L.C.A., Penido, E.S., do Amarante, C.B. and Fernandes, A.R. (2019). Biochar produced from Amazonian agro-industrial wastes: properties and adsorbent potential of $\mathrm{Cd}^{2+}$ and $\mathrm{Cu}^{2+}$. Biochar, 1-12. https://doi.org/10.1007/s42773-019-00031-4

Diaz, M.A., De Ranson, I.U., Dorta, B., Banat, I.M., Blazquez, M.L., Gonzalez, F., Munoz, J.A. and Ballester, A. (2015). Metal removal from contaminated soils through bioleaching with oxidizing bacteria and rhamnolipid biosurfactants. Soil and Sediment Contamination: An International Journal, 24(1): 16-29. https://doi.org/10.1080/15320383.2014.907239

Dinis, M.D.L. and Fiuza, A. (2011). Exposure assessment to heavy metals in the environment: measures to eliminate or reduce the exposure to critical receptors. Environmental heavy metal pollution and effects on child mental development, Springer, Dordrecht, pp. 27-50.

Efome, JE., Rana, D., Matsuura, T. and Lan, C.Q. (2019). Effects of operating parameters and coexisting ions on the efficiency of heavy metal ions removal by nano-fibrous metal-organic framework membrane filtration process. Science of The Total Environment, 674: 355-362. https://doi.org/10.1016/j.scitotenv.2019.04.187

Elazzouzi, M., Haboubi, K. and Elyoubi, M.S. (2019). Enhancement of electrocoagulation-flotation process for urban wastewater treatment using $\mathrm{Al}$ and Fe electrodes: techno-economic study. Materials Today: Proceedings, 13: 549-555. https://doi.org/10.1016/j.matpr.2019.04.012

El-Naggar, N.E.A., Hamouda, R.A., Mousa, I.E., Abdel-Hamid, M.S. and Rabei, N.H. (2018). Biosorption optimization, characterization, immobilization and application of Gelidium amansii biomass for complete $\mathrm{Pb}^{2+}$ removal from aqueous solutions. Scientific Reports, 8(1): 1-19. https://doi.org/10.1038/s41598-018-31660-7

Esmaeili, A., Mobini, M. and Eslami, H. (2019). Removal of heavy metals from acid mine drainage by native natural clay minerals, batch and continuous studies. Applied Water Science, 9(4): 97. https://doi.org/10.1007/s13201-019-0977-x

Ezeanyagu, P.I., Okafor, C.E. and Omenyi, S.N. (2018). Predictive models for cutting force in turning tools based on response surface methodology. Review of Industrial Engineering Letters, 4(1): 1-11 https://doi.org/10.18488/ journal.71/2018.41.1.11

Feng, G., Ma, J., Zhang, X., Zhang, Q., Xiao, Y., Ma, Q. and Wang, S. (2019). Magnetic natural composite Fe3O4-chitosan@ bentonite for removal of heavy metals from acid mine drainage. Journal of Colloid and Interface Science, 538: $132-141$. https://doi.org/10.1016/j.jhazmat.2013.12.062

Fu, F., Dionysiou, D.D. and Liu, H. (2014). The use of zero-valent iron for groundwater remediation and wastewater treatment: a review. Journal of Hazardous Materials, 267: 194-205. https://doi.org/10.1016/j.jhazmat.2013.12.062

Ghaith, E.S.I., Rizvi, S., Namasivayam, C. and Rahman, P.K.S.M. (2019). Removal of Cd²+ from contaminated water using biosurfactant modified ground grass as a bio-sorbent. Advances in Science and Engineering Technology International Conferences (ASET), IEEE, pp. 1-7.

Giwa, A., Dindi, A. and Kujawa, J. (2019). Membrane bioreactors and electrochemical processes for treatment of wastewaters 
containing heavy metal ions, organics, micropollutants and dyes: Recent developments. Journal of Hazardous Materials, 370: 172-195. https:// doi.org/10.1016/j.jhazmat.2018.06.025

Guyo, U., Phiri, L.Y. and Chigondo, F. (2017). Application of central composite design in the adsorption of Ca(II) on metakaolin zeolite. Journal of Chemistry, 2017. https://doi.org/10.1155/2017/7025073

Hailu, S.L., Nair, B.U., Redi-Abshiro, M., Diaz, I. and Tessema, M. (2017). Preparation and characterization of cationic surfactant modified zeolite adsorbent material for adsorption of organic and inorganic industrial pollutants. Journal of Environmental Chemical Engineering, 5(4): 3319-3329. https://doi.org/10.1016/j.jece.2017.06.039

Haryanto, B. and Chang, C.H. (2015). Removing adsorbed heavy metal ions from sand surfaces via applying interfacial properties of rhamnolipid. Journal of Oleo Science, 64(2): 161-168. https://doi.org/10.5650/jos.ess14058

He, J., Bardelli, F., Gehin, A., Silvester, E. and Charlet, L. (2016). Novel chitosan goethite bionanocomposite beads for arsenic remediation. Water Research, 101: 1-9. https:// doi.org/10.1016/j.watres.2016.05.032

Hino, K., Nishina, S., Sasaki, K. and Hara, Y. (2019). Mitochondrial damage and iron metabolic dysregulation in hepatitis C virus infection. Free Radical Biology and Medicine, 133: 193-199. https://doi.org/10.1016/j.freeradbiomed.2018.09.044

Hisham, M.B., Hanisah, N., Ibrahim, M.F., Ramli, N. and Abd-Aziz, S. (2019). Production of biosurfactant produced from used cooking oil by Bacillus sp. HIP3 for heavy metals removal. Molecules, 24(14): 2617. https://doi.org/10.3390/ molecules 24142617

Hubadillah, S.K., Othman, M.H.D., Harun, Z., Ismail, A.F., Rahman, M.A. and Jaafar, J. (2017). A novel green ceramic hollow fiber membrane (CHFM) derived from rice husk ash as combined adsorbent-separator for efficient heavy metals removal. Ceramics International, 43(5): 4716-4720. https://doi.org/10.1016/j.ceramint.2016.12.122

Huang, J., Huang, Z.L., Zhou, J.X., Li, C.Z., Yang, Z.H., Ruan, M., Li, H., Zhang, X., Wu, Z.J., Qin, X.L., and Hu, J.H. (2019). Enhancement of heavy metals removal by microbial flocculant produced by Paenibacillus polymyxa combined with an insufficient hydroxide precipitation. Chemical Engineering Journal, 374: 880-894. https://doi.org/10.1016/j.cej.2019.06.009

Hussain, C.M. and Mishra, A.K. (2018). Polymer nanocomposites, in: Hussain, C.M. and Mishra, A.K. (Eds.), New Polymer Nanocomposites for Environmental Remediation. Elsevier, pp. 1-21.

Hussain, M., Ullah, S.H., Baqi, A., Jabeen, R. and Khattak, M.I. (2019). 99. Study of heavy metals (Cd, Cu, Ni, Pb and Zn) in some medicinal plant species (Hertia intermedia, Cardaria chalepense, Scorzonera ammophila, Tamarix karelini, Astragalus auganus) at Pishin area in Balochistan, Pakistan. Pure and Applied Biology (PAB), 8(1): 995-1007. https:// doi.org/10.19045/bspab.2019.80040

Ifthikar, J., Jiao, X., Ngambia, A., Wang, T., Khan, A., Jawad, A., Xue, Q., Liu, L. and Chen, Z. (2018). Facile one-pot synthesis of sustainable carboxymethyl chitosan-sewage sludge biochar for effective heavy metal chelation and regeneration. Bioresource Technology, 262: 22-31. https://doi.org/10.1016/j.biortech.2018.04.053

Jaiswal, V., Saxena, S., Kaur, I., Dubey, P., Nand, S., Naseem, M., Singh, S.B., Srivastava, P.K. and Barik, S.K. (2018). Application of four novel fungal strains to remove arsenic from contaminated water in batch and column modes. Journal of Hazardous Materials, 356: 98-107. https://doi.org/10.1016/j.jhazmat.2018.04.053

Javanbakht, V., Alavi, S.A. and Zilouei, H. (2014). Mechanisms of heavy metal removal using microorganisms as biosorbent. Water Science and Technology, 69(9): 1775-1787. https://doi.org/10.2166/wst.2013.718

Jimoh, A.A. and Lin, J. (2020). Biotechnological applications of Paenibacillus sp. D9 lipopeptide biosurfactant produced in lowcost substrates. Applied Biochemistry and Biotechnology, 1-21. https://doi.org/10.1007/s12010-020-03246-5

Jiménez-Castañeda, M.E. and Medina, D.I. (2017). Use of surfactant-modified zeolites and clays for the removal of heavy metals from water. Water, 9(4): 235.https://doi.org/10.3390/w9040235

Jin, X., Xiang, Z., Liu, Q., Chen, Y. and Lu, F. (2017). Polyethyleneimine-bacterial cellulose bioadsorbent for effective removal of copper and lead ions from aqueous solution. Bioresource Technology, 244: 844-849. https://doi.org/10.1016/ j.biortech.2017.08.072

Kalaimurugan, D., Balamuralikrishnan, B., Durairaj, K., Vasudhevan, P., Shivakumar, M.S., Kaul, T., Chang, S.W., Ravindran, B. and Venkatesan, S. (2019). Isolation and characterization of heavy-metal-resistant bacteria and their applications in environmental bioremediation. International Journal of Environmental Science and Technology, 17: 1455-1465. https:// doi.org/10.1007/s13762-019-02563-5 
Kobayashi, Y., Ogata, F., Nakamura, T. and Kawasaki, N. (2020). Synthesis of novel zeolites produced from fly ash by hydrothermal treatment in alkaline solution and its evaluation as an adsorbent for heavy metal removal. Journal of Environmental Chemical Engineering, 103687. https:// doi.org/10.1016/j.jece.2020.103687

Koptsik, G.N. (2014). Modern approaches to remediation of heavy metal polluted soils: a review. Eurasian Soil Science, 47(7): 707-722. https:// doi.org/10.1134/S1064229314070072

Kumar, V., Singh, J., Kumar, P., Kumar, P. (2019). Response surface methodology based electro-kinetic modeling of biological and chemical oxygen demand removal from sugar mill effluent by water hyacinth (Eichhornia crassipes) in a Continuous Stirred Tank Reactor (CSTR). Environmental Technology \& Innovation, 14, 100327. https://doi.org/10.1016/ j.eti.2019.100327

Kyzas, G.Z., Bomis, G., Kosheleva, R.I., Efthimiadou, E.K., Favvas, E.P., Kostoglou, M. and Mitropoulos, A.C. (2019). Nanobubbles effect on heavy metal ions adsorption by activated carbon. Chemical Engineering Journal, 356: 91-97. https:// doi.org/10.1016/j.cej.2018.09.019

Lee, A. and Kim, K. (2019). Removal of heavy metals using rhamnolipid biosurfactant on manganese nodules. Water, Air, and Soil Pollution, 230(11): 258. https://doi.org/10.1007/s11270-019-4319-2

$\mathrm{Li}, \mathrm{D}$. and Zhou, L. (2018). Adsorption of heavy metal tolerance strains to $\mathrm{Pb}^{2+}$ and $\mathrm{Cd}^{2+}$ in wastewater. Environmental Science and Pollution Research, 25(32): 32156-32162. https://doi.org/10.1007/s11356-018-2988-9

Li, Z., Beachner, R., McManama, Z. and Hanlie, H. (2007). Sorption of arsenic by surfactant-modified zeolite and kaolinite. Microporous and Mesoporous Materials, 105(3): 291-297. https://doi.org/10.1016/j.micromeso.2007.03.038

Liang, Y., Chen, J.Q., Mei, J., Chang, J.J., Wang, Q.Y., Wan, G.S. and Yin, B.Y. (2019). Characterization of Cu and Cd biosorption by Pseudomonas sp. strain DC-B3 isolated from metal mine soil. International Journal of Environmental Science and Technology, 16(8): 4035-4046. https://doi.org/10.1007/s13762-018-2011-5

Liu, J., Chen, Y., Han, T., Cheng, M., Zhang, W., Long, J. and Fu, X. (2019). A biomimetic $\mathrm{SiO}_{2} @$ chitosan composite as highlyefficient adsorbent for removing heavy metal ions in drinking water. Chemosphere, 214: 738-742. https:// doi.org/10.1016/j.chemosphere.2018.09.172

Liu, J., Mwamulima, T., Wang, Y., Fang, Y., Song, S. and Peng, C. (2017). Removal of Pb(II) and Cr(VI) from aqueous solutions using the fly ash-based adsorbent material-supported zero-valent iron. Journal of Molecular Liquids, 243: 205-211. https://doi.org/10.1016/j.micromeso.2007.03.038

Liu, L., Li, W., Song, W. and Guo, M. (2018). Remediation techniques for heavy metal-contaminated soils: principles and applicability. Science of the Total Environment, 633: 206-219. https://doi.org/10.1016/j.scitotenv.2018.03.161

Luo, H., Feng, F., Yao, F., Zhu, Y., Yang, Z. and Wan, Y. (2020). Improved Removal of Toxic Metal Ions by Incorporating Graphene Oxide into Bacterial Cellulose. Journal of Nanoscience and Nanotechnology, 20(2): 719-730. https:// doi.org/10.1166/jnn.2020.16902

Ma, A., Abushaikha, A., Allen, S.J. and McKay, G. (2019). Ion exchange homogeneous surface diffusion modelling by binary site resin for the removal of nickel ions from wastewater in fixed beds. Chemical Engineering Journal, 358: 1-10. https:// doi.org/10.1016/j.cej.2018.09.135

Ma, L., Chen, Q., Zhu, J., Xi, Y., He, H., Zhu, R., and Ayoko, G.A. (2016). Adsorption of phenol and Cu (II) onto cationic and zwitterionic surfactant modified montmorillonite in single and binary systems. Chemical Engineering Journal, 283: 880888. https://doi.org/10.1016/j.cej.2015.08.009

Mahmud, H.N.M.E., Huq, A.O. and binti Yahya, R. (2016). The removal of heavy metal ions from wastewater/aqueous solution using polypyrrole-based adsorbents: a review. RSC Advances, 6(18): 14778-14791. https://doi.org/10.1039/ C5RA24358K

Mbachu, A.E., Mbachu, N.A. and Chukwura, E.I. (2019). pH-dependent heavy metal toxicity differentials in fungal isolates during biodegradation of spent engine oil. American Journal of Current Microbiology, 7(1): 1-11.

Meseldzija, S., Petrovic, J., Onjia, A., Volkov-Husovic, T., Nesic, A. and Vukelic, N. (2019). Utilization of agro-industrial waste for removal of copper ions from aqueous solutions and mining-wastewater. Journal of Industrial and Engineering Chemistry, 75: 246-252. https://doi.org/10.1016/j.jiec.2019.03.031 
Mohammed, K., Worku, K. and Sahu, O. (2015). Bio-chemical separations and purification of heavy metal from industrial waste water: A Review on Adsorption and Precipitations. Journal of Hydrology and Environment Research, 3(1): 38-47.

Mulligan, C.N., Yong, R.N. and Gibbs, B.F. (2001). Surfactant-enhanced remediation of contaminated soil: a review. Engineering Geology, 60(1-4): 371-380. https://doi.org/10.1016/S0013-7952(00)00117-4

Naga Babu, A., Krishna Mohan, G.V., Kalpana, K. and Ravindhranath, K. (2017). Removal of lead from water using calcium alginate beads doped with hydrazine sulphate-activated red mud as adsorbent. Journal of Analytical Methods in Chemistry, 2017: 1-13. https://doi.org/10.1155/2017/4650594

Narimannejad, S., Zhang, B. and Lye, L. (2019). Adsorption behavior of cobalt onto saline soil with/without a biosurfactant: kinetic and isotherm studies. Water, Air, E Soil Pollution, 230(2): 47. https:// doi.org/10.1007/s11270-019-4097-x

Navasumrit, P., Chaisatra, K., Promvijit, J., Parnlob, V., Waraprasit, S., Chompoobut, C., Binh, T.T., Hai, D.N., Bao, N.D., Hai, N.K., Kim, K.W., Samson, L.D., Graziano, J.H., Mahidol, C. and Ruchirawat M. (2019). Exposure to arsenic in utero is associated with various types of DNA damage and micronuclei in newborns: a birth cohort study. Environmental Health, 18(1): 51. https://doi.org/10.1186/s12940-019-0481-7

Nasir, A.M., Goh, P.S., Abdullah, M.S., Cheer, N.B. and Ismail, A.F. (2019). Adsorptive nanocomposite membranes for heavy metal remediation: Recent progresses and challenges. Chemosphere. 232: 96-112. https://doi.org/10.1016/ j.chemosphere.2019.05.174

Nemati, M., Hosseini, S.M., Parvizian, F., Rafiei, N. and Van der Bruggen, B. (2019). Desalination and heavy metal ion removal from water by new ion exchange membrane modified by synthesized $\mathrm{NiFe}_{2} \mathrm{O}_{4} /$ HAMPS nanocomposite. Ionics, 25(8): 3847-3857. https://doi.org/10.1007/s11581-019-02937-2

Nguyen, T.C., Loganathan, P., Nguyen, T.V., Kandasamy, J., Naidu, R. and Vigneswaran, S. (2018). Adsorptive removal of five heavy metals from water using blast furnace slag and fly ash. Environmental Science and Pollution Research, 25(21): 20430-20438. https://doi.org/10.1007/s11356-017-9610-4

Ob, A. and Muchie, M. (2010). Remediation of heavy metals in drinking water and wastewater treatment systems: Processes and applications. International Journal of the Physical Sciences, 5(12): 1807-1817.

Pankow, J. F. and Cherry, J. A. (1996). Dense chlorinated solvents and other DNAPLs in groundwater: History, behaviour, and remediation, Waterloo Press, Portland.

Pavón, N., Buelna-Chontal, M., Macías-López, A., Correa, F., Uribe-Alvarez, C., Hernández-Esquivel, L. and Chávez, E. (2019). On the oxidative damage by cadmium to kidney mitochondrial functions. Biochemistry and Cell Biology, 97(2): 187 -192. https://doi.org/10.1139/bcb-2018-0196

Poole, K., Hay, T., Gilmour, C. and Fruci, M. (2019). The aminoglycoside resistance-promoting AmgRS envelope stressresponsive two-component system in Pseudomonas aeruginosa is zinc-activated and protects cells from zinc-promoted membrane damage. Microbiology, 165(5): 563-571. https://doi.org/10.1099/mic.0.000787

Posati, T., Nocchetti, M., Kovtun, A., Donnadio, A., Zambianchi, M., Aluigi, A., Capobianco, M.L., Corticelli, F., Palermo, V., Ruani, G., Zamboni, R., Navacchia, M.L. and Melucci, M. (2019). Polydopamine nanoparticle-coated polysulfone porous granules as adsorbents for water remediation. ACS Omega, 4(3): 4839-4847. https://doi.org/10.1021/acsomega.8b02900

Pourfadakari, S., Ahmadi, M., Jaafarzadeh, N., Takdastan, A., Neisi, A.A., Ghafari, S. and Jorfi, S. (2019). Remediation of PAHs contaminated soil using a sequence of soil washing with biosurfactant produced by Pseudomonas aeruginosa strain $\mathrm{PF}_{2}$ and electrokinetic oxidation of desorbed solution, effect of electrode modification with $\mathrm{Fe}_{3} \mathrm{O}_{4}$ nanoparticles. Journal of Hazardous Materials, 379: 120839. https://doi.org/10.1016/j.jhazmat.2019.120839

Priyantha, N. and Kotabewatta, P.A. (2019). Biosorption of heavy metal ions on peel of Artocarpus nobilis fruit: $1-\mathrm{Ni}$ (II) sorption under static and dynamic conditions. Applied Water Science, 9(2): 37. https:// doi.org/10.1007/s13201-019-0911

Qi, X., Xu, X., Zhong, C., Jiang, T., Wei, W. and Song, X. (2018). Removal of cadmium and lead from contaminated soils using sophorolipids from fermentation culture of Starmerella bombicola CGMCC 1576 fermentation. International Journal of Environmental Research and Public Health, 15(11): 2334. https://doi.org/10.3390/ijerph15112334

Rajamani, M. and Rajendrakumar, K. (2019). Chitosan-boehmite desiccant composite as a promising adsorbent towards heavy metal removal. Journal of Environmental Management, 244: 257-264. https://doi.org/10.1016/j.jenvman.2019.05.056

Rajendran, P., Muthukrishnan, J. and Gunasekaran, P. (2003). Microbes in heavy metal remediation. Indian Journal of 
Experimental Biology, 41(9): 935-944.

Rangabhashiyam, S., Jayabalan, R., Rajkumar, M.A. and Balasubramanian, P. (2019). Elimination of toxic heavy metals from aqueous systems using potential biosorbents: a review. Green Buildings and Sustainable Engineering, Springer, Singapore, pp. 291-311.

Rastogi, S., Kumar, J. and Kumar, R. (2019). An investigation into the efficacy of fungal biomass as a low-cost bio-adsorbent for the removal of lead from aqueous solutions. International Research Journal of Engineering and Technology (IRJET), 6(3): 7144-7149.

Rosales, E., Escudero, S., Pazos, M. and Sanromán, M. (2019). Sustainable removal of Cr(vi) by lime peel and pineapple core wastes. Applied Sciences, 9(10): 1967. https://doi.org/10.3390/app9101967

Saleem, H., Pal, P., Haija, M.A. and Banat, F. (2019). Regeneration and reuse of bio-surfactant to produce colloidal gas aphrons for heavy metal ions removal using single and multistage cascade flotation. Journal of Cleaner Production, 217: 493-502. https://doi.org/10.1016/j.jclepro.2019.01.216

Sangeetha, J., Thangadurai, D., Hospet, R., Purushotham, P., Manowade, K.R., Mujeeb, M.A., Mundaragi, A.C., Jogaiah, S., David, M., Thimmappa, S.C., Prasad, R. and Harish, E.R. (2017). Production of bionanomaterials from agricultural wastes. Nanotechnology, Springer, Singapore, pp. 33-58.

Sarkar, A., Ranjan, A. and Paul, B. (2019). Synthesis, characterization and application of surface-modified biochar synthesized from rice husk, an agro-industrial waste for the removal of hexavalent chromium from drinking water at near-neutral pH. Clean Technologies and Environmental Policy, 21(2): 447-462. https://doi.org/10.1007/s10098-018-1649-5

Sarkar, S., Sarkar, S. and Biswas, P. (2017). Effective utilization of iron ore slime, a mining waste as adsorbent for removal of $\mathrm{Pb}$ (II) and $\mathrm{Hg}$ (II). Journal of Environmental Chemical Engineering, 5(1): 38-44. https://doi.org/10.1016/j.jece.2016.11.015

Sarubbo, L.A., Rocha Jr, R.B., Luna, J.M., Rufino, R.D., Santos, V.A. and Banat, I.M. (2015). Some aspects of heavy metals contamination remediation and role of biosurfactants. Chemistry and Ecology, 31(8): 707-723. https:// doi.org/10.1080/02757540.2015.1095293

Shahat, A., Awual, M. R. and Naushad, M. (2015). Functional ligand anchored nanomaterial based facial adsorbent for cobalt (II) detection and removal from water samples. Chemical Engineering Journal, 271: 155-16. https://doi.org/10.1016/ j.cej.2015.02.097

Shahid, M., Javed, M.T., Mushtaq, A., Akram, M.S., Mahmood, F., Ahmed, T., Noman, M. and Azeem, M. (2019). Microbemediated mitigation of cadmium toxicity in plants. cadmium toxicity and tolerance in plants, Academic Press, pp. 427449.

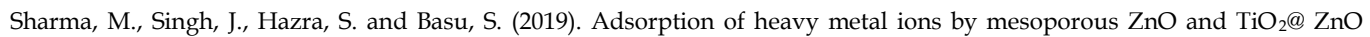
monoliths: adsorption and kinetic studies. Microchemical Journal, 145: 105-112. https://doi.org/10.1016/ j.microc.2018.10.026

Shen, C., Tang, S. and Meng, Q. (2019). Cadmium removal from rice protein via synergistic treatment of rhamnolipids and F127/PAA hydrogels. Colloids and Surfaces B: Biointerfaces, 181: 734-739. https://doi.org/10.1016/j.colsurfb.2019.06.019

Snyder, S.A., Westerhoff, P., Yoon, Y. and Sedlak, D.L. (2003). Pharmaceuticals, personal care products, and endocrine disruptors in water: implications for the water industry. Environmental Engineering Science, 20(5): 449-469.

Souza, W.D., Rodrigues, W.S., Lima Filho, M.M., Alves, J.J. and Oliveira, T.M. (2018). Heavy metals uptake on Malpighia emarginata DC seed fiber microparticles: Physicochemical characterization, modeling and application in landfill leachate. Waste Management, 78: 356-36. https://doi.org/10.1016/j.wasman.2018.06.004

Tang, J., He, J., Liu, T., Xin, X. and Hu, H. (2017). Removal of heavy metal from sludge by the combined application of a biodegradable biosurfactant and complexing agent in enhanced electrokinetic treatment. Chemosphere, 189: 599-608. https://doi.org/10.1016/j.chemosphere.2017.09.104

Tang, J., He, J., Qiu, Z. and Xin, X. (2019). Metal removal effectiveness, fractions, and binding intensity in the sludge during the multiple washing steps using the combined rhamnolipid and saponin. Journal of Soils and Sediments, 19(3): 1286-1296. https://doi.org/10.1007/s11368-018-2106-0

Taseidifar, M., Ziaee, M., Pashley, R.M. and Ninham, B.W. (2019). Ion flotation removal of a range of contaminant ions from 
drinking water. Journal of Environmental Chemical Engineering, 7(4): 103263. https://doi.org/10.1016/j.jece.2019.103263

Tortora, F., Innocenzi, V., Prisciandaro, M., Vegliò, F. and Di Celso, G.M. (2016). Heavy metal removal from liquid wastes by using micellar-enhanced ultrafiltration. Water, Air, \& Soil Pollution, 227(7): 240. https://doi.org/10.1007/s11270-0162935-7

Tran, H.N., Van Viet, P. and Chao, H.P. (2018). Surfactant modified zeolite as amphiphilic and dual-electronic adsorbent for removal of cationic and oxyanionic metal ions and organic compounds. Ecotoxicology and Environmental Safety, 147: 5563. https://doi.org/10.1016/j.ecoenv.2017.08.027

Tsamo, C., Djonga, P.D., Dikdim, J.D. and Kamga, R. (2018). Kinetic and equilibrium studies of $\mathrm{Cr}(\mathrm{VI}), \mathrm{Cu}(\mathrm{II})$ and $\mathrm{Pb}(\mathrm{II}) \mathrm{re-}$ moval from aqueous solution using red mud, a low-cost adsorbent. Arabian Journal for Science and Engineering, 43(5): 2353-2368. https://doi.org/10.1007/s13369-017-2787-5

Ucankus, G., Ercan, M., Uzunoglu, D. and Culha, M. (2018). Methods for preparation of nanocomposites in environmental remediation. New Polymer Nanocomposites for Environmental Remediation, Elsevier, pp. 1-28.

Usman, M.M., Dadrasnia, A., Lim, K.T., Mahmud, A.F. and Ismail, S. (2016). Application of biosurfactants in environmental biotechnology; remediation of oil and heavy metal. AIMS Bioengineering, 3(3): 289-304. https://doi.org/10.3934/ bioeng.2016.3.289

Vafaeifard, M., Ibrahim, S., Wong, K.T., Pasbakhsh, P., Pichiah, S., Choi, J., and Jang, M. (2019). Novel self-assembled 3D flower-like magnesium hydroxide coated granular polyurethane: Implication of its potential application for the removal of heavy metals. Journal of Cleaner Production, 216: 495-503. https://doi.org/10.1016/j.jclepro.2018.12.135

Vojoudi, H., Badiei, A., Bahar, S., Ziarani, G. M., Faridbod, F. and Ganjali, M.R. (2017). A new nano-sorbent for fast and efficient removal of heavy metals from aqueous solutions based on modification of magnetic mesoporous silica nanospheres. Journal of Magnetism and Magnetic Materials, 441: 193-203. https://doi.org/10.1016/j.jmmm.2017.05.065

Wan, J., Zeng, G., Huang, D., Hu, L., Xu, P., Huang, C., Deng, R., Xue, W., Lai, C., Zhou, C., Zheng, K., Ren, X. and Gong, X. (2018). Rhamnolipid stabilized nano-chlorapatite: synthesis and enhancement effect on Pb-and Cd-immobilization in polluted sediment. Journal of Hazardous Materials, 343: 332-339. https://doi.org/10.1016/j.jhazmat.2017.09.053

Wan, J., Tokunaga, T.K., Dong, W. and Kim, Y. (2017). Extracting natural biosurfactants from humus deposits for subsurface engineering applications. Energy \& Fuels, 31(11): 11902-11910. https://doi.org/10.1021/acs.energyfuels.7b02203

Wang, J., Liu, M., Duan, C., Sun, J. and Xu, Y. (2019). Preparation and characterization of cellulose-based adsorbent and its application in heavy metal ions removal. Carbohydrate Polymers, 206: 837-843. https://doi.org/10.1016/ j.carbpol.2018.11.059

Wang, S. and Mulligan, C.N. (2009). Rhamnolipid biosurfactant-enhanced soil flushing for the removal of arsenic and heavy metals from mine tailings. Process Biochemistry, 44(3): 296-301. https://doi.org/10.1016/j.procbio.2008.11.006

Wu, J., Zhang, J., Wang, P., Zhu, L., Gao, M., Zheng, Z. and Zhan, X. (2017). Production of rhamnolipids by semi-solid-state fermentation with Pseudomonas aeruginosa RG18 for heavy metal desorption. Bioprocess and Biosystems Engineering, 40 (11): 1611-1619. https:// doi.org/10.1007/s00449-017-1817-8

$\mathrm{Wu}$, R. (2019). Removal of heavy metal ions from industrial wastewater based on chemical precipitation method. Ekoloji Dergisi, 28(107): 2443-2452.

Xie, W.M., Zhou, F.P., Bi, X.L., Chen, D.D., Li, J., Sun, S.Y., Liu, J.Y. and Chen, X.Q. (2018). Accelerated crystallization of magnetic 4A-zeolite synthesized from red mud for application in removal of mixed heavy metal ions. Journal of Hazardous Materials, 358: 441-449. https:// doi.org/10.1016/j.jhazmat.2018.07.007

Xu, S., Xing, Y., Liu, S., Hao, X., Chen, W. and Huang, Q. (2020). Characterization of Cd ${ }^{2+}$ biosorption by Pseudomonas sp. strain 375, a novel biosorbent isolated from soil polluted with heavy metals in Southern China. Chemosphere, $240: 124893$. https://doi.org/10.1016/j.chemosphere.2019.124893

Xue, W., Huang, D., Zeng, G., Wan, J., Zhang, C., Xu, R., Cheng, M. and Deng, R. (2018). Nanoscale zero-valent iron coated with rhamnolipid as an effective stabilizer for immobilization of $\mathrm{Cd}$ and $\mathrm{Pb}$ in river sediments. Journal of Hazardous Materials, 341: 381-389. https:// doi.org/10.1016/j.jhazmat.2017.06.028

Yang, X., Wan, Y., Zheng, Y., He, F., Yu, Z., Huang, J., Wang, H., Ok, Y.S., Jiang, Y. and Gao, B. (2019). Surface functional groups of carbon-based adsorbents and their roles in the removal of heavy metals from aqueous solutions: a critical 
review. Chemical Engineering Journal, 366: 608-621. https://doi.org/10.1016/j.cej.2019.02.119

Yang, Z., Shi, W., Yang, W., Liang, L., Yao, W., Chai, L., Gao S. and Liao, Q. (2018). Combination of bioleaching by gross bacterial biosurfactants and flocculation: A potential remediation for the heavy metal contaminated soils. Chemosphere, 206: 83-91. https://doi.org/10.1016/j.chemosphere.2018.04.166

Ye, C.C., An, Q.F., Wu, J.K., Zhao, F.Y., Zheng, P.Y. and Wang, N.X. (2019). Nanofiltration membranes consisting of quaternized polyelectrolyte complex nanoparticles for heavy metal removal. Chemical Engineering Journal, 359: 994-1005. https://doi.org/10.1016/j.cej.2018.11.085

Zeng, G., He, Y., Zhan, Y., Zhang, L., Pan, Y., Zhang, C. and Yu, Z. (2016). Novel polyvinylidene fluoride nanofiltration membrane blended with functionalized halloysite nanotubes for dye and heavy metal ions removal. Journal of Hazardous Materials, 317: 60-72. https://doi.org/10.1016/j.jhazmat.2016.05.049

Zanin, E., Scapinello, J., de Oliveira, M., Rambo, C.L., Franscescon, F., Freitas, L., de Mello, J.M.M., Flori, M.A., Oliveira, J.V. and Dal Magro, J. (2017). Adsorption of heavy metals from wastewater graphic industry using clinoptilolite zeolite as adsorbent. Process Safety and Environmental Protection, 105: 194-200. https://doi.org/10.1016/j.psep.2016.11.008

Zhang, D., Wang, L., Zeng, H., Yan, P., Nie, J., Sharma, V.K. and Wang, C. (2019). A three-dimensional macroporous network structured chitosan/cellulose biocomposite sponge for rapid and selective removal of mercury (II) ions from aqueous solution. Chemical Engineering Journal, 363: 192-202. https://doi.org/10.1016/j.cej.2019.01.127

Zhu, W., Wang, J., Wu, D., Li, X., Luo, Y., Han, C., Ma, W. and He, S. (2017). Investigating the heavy metal adsorption of mesoporous silica materials prepared by microwave synthesis. Nanoscale Research Letters, 12(1): 1-9. https:// doi.org/10.1186/s11671-017-2070-4

$\star \star \star \star \star *$

Cite this chapter as: Rastogi, S. and Kumar, R. (2020). Remediation of heavy metals using non-conventional adsorbents and biosurfactant-producing bacteria. In: Environmental Degradation: Causes and Remediation Strategies, Volume 1, Eds. Kumar, V., Singh, J. and Kumar, P., pp. 133-153, https://doi.org/10.26832/aesa-2020-edcrs-010 